\title{
Renal dysplasia, unilateral
}

INSERM

\section{Source}

INSERM. (1999). Orphanet: an online rare disease and orphan drug data base. Renal dysplasia, unilateral. ORPHA:93172

Unilateral renal dysplasia is a form of renal dysplasia (RD; see this term), a renal tract malformation in which the development of one kidney is abnormal and incomplete. Unilateral RD can be segmental, and of variable severity, with renal aplasia corresponding to extreme RD. 